\title{
ANALISIS PENGARUH FAKTOR-FAKTOR PRODUKSI TERHADAP PRODUKSI USAHATANI BAWANG MERAH DI KECAMATAN WANASARI KABUPATEN BREBES
}

\section{(Analysis of Determinant Factors of Red Onion Farm Production in Wanasari District Brebes)}

\author{
H. Susanti, K. Budiraharjo, dan M. Handayani \\ Program Studi S1 Agribisnis Fakultas Peternakan dan Pertanian Universitas Diponegoro \\ Email: herasusanti00@gmail.com
}

Diterima 8 Desember 2017, disetujui 12 Februari 2018

\begin{abstract}
ABSTRAK
Penelitian ini bertujuan untuk menganalisis pengaruh faktor-faktor produksi (luas lahan, bibit, tenaga kerja, pupuk organik, pupuk NPK, dan pestisida) terhadap jumlah produksi usahatani bawang merah, di Kecamatan Wanasari Kabupaten Brebes. Penelitian dilakukan menggunakan metode survei di lokasi Kecamatan Wanasari Kabupaten Brebes. Metode penentuan lokasi desa ditentukan melalui proses bergulir dari Dinas Pertanian Kabupaten Brebes, yaitu berturut-turut Desa Wanasari, Desa Siasem, Desa Sisalam, Desa Kupu, dan Desa Sidamulya. Metode pengambilan sampel responden dilakukan secara kuota, masing-masing desa diambil sebanyak 18 petani, sehingga jumlah keseluruhan sebanyak 90 responden. Analisis yang digunakan adalah regresi linier berganda. Hasil penelitian menunjukkan faktor produksi yang berpengaruh nyata terhadap produksi bawang merah adalah luas lahan, bibit, tenaga kerja, pupuk organik, pupuk NPK, dan pestisida.
\end{abstract}

Kata kunci: bawang merah, faktor produksi, pupuk, usahatani

\begin{abstract}
This study aimed to analyze the influence of production factors, (an area of Land area, seed, labor, organic fertilizer, NPK fertilizer, and pesticides) to the production of red onion, in the Wanasari District Brebes Region. The research was conducted using survey method. The research location was determined through the process of rolling from the Agriculture Department of Brebes Regency, namely Wanasari Village, Siasem Village, Sisalam Village, Kupu Village, and Sidamulya Village. Sampling method was conducted by quota, each village was taken as many as 18 farmers, so the total number of respondent was 90 . Data were analyzed by multiple linear regression. The results of this research found that land area, labor, organic fertilizer and pesticide were significantly influenced the red onion production.
\end{abstract}

Keywords: red onion, factors production, fertilizer, farm

\section{PENDAHULUAN}

Bawang merah merupakan salah satu komoditas sayuran unggulan yang sejak lama telah diusahakan oleh petani secara intensif.
Komoditas sayuran ini termasuk ke dalam kelompok rempah tidak bersubstitusi yang berfungsi sebagai bumbu penyedap makanan serta obat tradisional. Komoditas ini juga 
merupakan sumber pendapatan dan kesempatan kerja yang memberikan kontribusi cukup tinggi terhadap perkembangan ekonomi wilayah (Balitbang Pertanian, 2005).

Produktivitas bawang merah di Indonesia masih rendah dengan rata-rata 9,24 ton/ha produktivitas bawang merah nasional, jauh dibawah potensi produksi yaitu diatas 20 ton/ha (Kementerian Pertanian, 2014). Beberapa permasalahan rendahnya produktivitas bawang merah tersebut antara lain, penggunaan bibit yang kurang bermutu dan media tanam yang kurang baik (Rahmah dan Sipayung, 2013).

Kecamatan Wanasari Kabupaten Brebes merupakan salah satu sentra penghasil bawang merah. Produksi tersebut mengalami perubahan dari tahun ke tahun antara lain produksi pada tahun 2011 sebesar 593.470,00 kuintal, pada tahun 2012 sebesar 481.959,92 kuintal, pada tahun 2013 sebesar 432.195,08 kuintal dan pada tahun 2014 sebesar 404.562,20 kuintal (BPS, 2015). Hal ini dikarenakan perubahan luas lahan tanam dan produktivitas. Petani di Kecamatan Wanasari dihadapkan oleh beberapa kendala, diantaranya adalah lahan pertanian yang dimiliki oleh petani relatif sempit sehingga produksi bawang merah kecil dan belum dapat memenuhi kebutuhan dalam negeri.

Penurunan produksi tersebut mengakibatkan kurangnya pasokan bawang merah di pasar Brebes sehingga harga bawang merah di pasar melonjak tinggi sebesar Rp. 35.000,- dari harga normalnya Rp. 20.000,-. Kekurangan pasokan bawang merah tersebut selain faktor luas lahan yang sempit juga faktor minimnya stok bibit yang diperoleh petani karena telah berkali-kali mengalami gagal panen akibat penyakit dan hama tanaman menjadi pemicu produksi bawang merah yang dihasilkan menurun. Kurangnya stok benih yang didapat oleh petani berdampak juga terhadap kenaikan harga bibit yang melambung tinggi akibat stok bibit tersebut menipis.

Penggunaan tenaga kerja pada usahatani bawang merah di Kecamatan Wanasari
Kabupaten Brebes cukup banyak atau berlebihan (Rahmawati dan Istiyanti, 2011). Faktor produksi tenaga kerja merupakan faktor produksi penting dan perlu diperhitungkan dalam proses produksi (Novitasari, 2017).

Produksi bawang merah diantaranya dipengaruhi oleh pupuk, salah satu alternatif untuk meningkatkan pertumbuhan dan produksi bawang merah adalah melakukan pemupukan secara tepat (Istina, 2016). Penambahan unsur NPK dan $\mathrm{S}$ melebihi batas $100 \mathrm{~kg} / \mathrm{ha} \mathrm{N} 80 \mathrm{~kg} / \mathrm{ha} \mathrm{P} 50 \mathrm{~kg} / \mathrm{ha}$ dan K $30 \mathrm{~kg} / \mathrm{ha}$ tidak lagi meningkatkan hasil umbi bawang merah (Wiguna et al., 2013).

Upaya peningkatan produksi bawang merah sebagai salah satu tindakan pemeliharaan tanaman adalah penggunaan pestisida (Badrudin dan Jazilah, 2010). Pestisida adalah bahan kimia beracun, pemakaian pestisida yang berlebihan dapat menjadi sumber pencemar bagi bahan pangan, air, dan lingkungan hidup (Badrudin dan Jazilah, 2010).

Penelitian ini bertujuan untuk menganalisis faktor-faktor produksi (luas lahan, bibit, tenaga kerja, pupuk organik, pupuk NPK, dan pestisida) terhadap jumlah produksi bawang merah di Kecamatan Wanasari Kabupaten Brebes.

\section{METODE PENELITIAN}

Metode penelitian yang digunakan yaitu metode survei. Penelitian telah dilakukan pada bulan Maret sampai April 2017 di Kecamatan Wanasari Kabupaten Brebes. Metode penentuan lokasi desa diperoleh melalui proses bergulir dari Dinas Pertanian Kabupaten Brebes, yaitu berturut-turut Desa Wanasari, Desa Siasem, Desa Sisalam, Desa Kupu, Desa Sidamulya. Metode pengambilan sampel dilakukan secara kuota, masing-masing desa diambil sebanyak 18 petani, sehingga jumlah keseluruhan sebanyak 90 responden.

Analisis yang bertujuan untuk mengetahui pengaruh variabel prediktor atau independen (luas lahan, bibit, tenaga kerja, pupuk organik, pupuk NPK, dan pestisida) 
terhadap variabel dependen (produksi bawang merah) digunakan uji regresi linier berganda sehingga dapat memuat prediksi yang tepat (Pramesti, 2014).

Pengolahan data faktor-faktor produksi meliputi luas lahan usahatani bawang merah, jumlah bibit, tenaga kerja, pupuk organik, pupuk NPK, dan pestisida.

Analisis statistik regresi linier berganda yang digunakan adalah:

$\mathrm{Y}=\mathrm{a}+\mathrm{b}_{1} \mathrm{X}_{1}+\mathrm{b}_{2} \mathrm{X}_{2}+\mathrm{b}_{3} \mathrm{X}_{3}+\mathrm{b}_{4} \mathrm{X}_{4}+\mathrm{b}_{5} \mathrm{X}_{5}+$ $\mathrm{b}_{6} \mathrm{X}_{6}$

Keterangan :

$\mathrm{Y}=$ Produksi bawang merah ( $\mathrm{kg}$ per masa panen)

a $=$ Konstanta

$\mathrm{b} \quad=$ Koefisien regresi

$\mathrm{X}_{1}=$ Luas Lahan (ha/mt)

$\mathrm{X}_{2}=$ Jumlah Bibit $(\mathrm{kg} / \mathrm{mt})$

$\mathrm{X}_{3}=$ Tenaga Kerja $(\mathrm{HOK} / \mathrm{mt})$

$\mathrm{X}_{4}=$ Jumlah Pupuk Organik (kg/mt)

$\mathrm{X}_{5}=$ Jumlah Pupuk NPK $(\mathrm{kg} / \mathrm{mt})$

$\mathrm{X}_{6}=$ Jumlah Pestisida (liter/mt)

Uji serentak (uji F) bertujuan untuk mengetahui pengaruh variabel bebas secara bersama-sama terhadap variabel terikat. (Ghozali, 2007).

Rumus: $\mathrm{F}=\frac{U / v 1}{V / v 1}$

Keterangan:

$\mathrm{U}$ dan $\mathrm{V}$ menyatakan peubah acak bebas masing-masing berdistribusi khi-kuadrat dengan derajat kebebasan $v_{1}$ dan $v_{2}$

Hipotesis statistik:

Ho : $b_{1}=b_{2}=b_{3}=b_{4}=b_{5}=b_{6}=0$, secara serempak tidak ada pengaruh yang signifikan antara variabel independen terhadap variabel dependen.

Hi $: b_{1} \neq b_{2} \neq b_{3} \neq b_{4} \neq b_{5} \neq b_{6} \neq 0$, secara

serempak ada pengaruh yang signifikan antara variabel independen terhadap variabel dependen.

Kriteria Pengujian :

1. Jika signifikansi $\mathrm{F}>0,05 \mathrm{H} 0$ diterima H1 ditolak (artinya secara serempak tidak ada pengaruh yang signifikan antara luas lahan, bibit, tenaga kerja, pupuk organik, pupuk NPK, dan pestisida terhadap produksi bawang merah di Kecamatan Wanasari).

2. Jika signifikansi $\mathrm{F} \leq 0,05 \mathrm{H} 1$ diterima H0 ditolak (artinya serempak terdapat pengaruh yang signifikan antara luas lahan, bibit, tenaga kerja, pupuk organik, pupuk NPK, dan pestisida terhadap produksi bawang merah di Kecamatan Wanasari).

Uji parsial (uji t) bertujuan untuk mengetahui pengaruh variabel bebas secara individual terhadap variabel terikat (Ghozali, 2007).

Rumus: t hit $=\frac{b i}{s b i}$

Keterangan :

$\mathrm{t}$ hit $=\mathrm{t}$ hitung

bi $=$ Koefisien regresi parsial

Sbi $=$ Standar error koefisien standar parsial Hipotesis statistik:

Ho : $b_{1}=0 ; b_{2}=0 ; \quad b_{3}=0 ; \quad b_{4}=0 ; b_{5}=0, \quad b_{6}=0$ secara parsial tidak ada pengaruh yang signifikan antara variabel independen terhadap variabel dependen.

Hi : $b_{1} \neq 0 ; \quad b_{2} \neq 0 ; \quad b_{3} \neq 0 ; \quad b_{4} \neq 0 ; \quad b_{5} \neq 0, \quad b_{6} \neq 0$ secara parsial ada pengaruh yang signifikan antara variabel independen terhadap variabel dependen.

Kriteria Pengujian:

1. Jika signifikansi $\mathrm{t}>0,05 \mathrm{H} 0$ diterima $\mathrm{H} 1$ ditolak (artinya secara parsial tidak ada pengaruh yang signifikan antara luas lahan, bibit, tenaga kerja, pupuk organik, pupuk NPK, dan pestisida terhadap produksi bawang merah di Kecamatan Wanasari).

2. Jika signifikansi $\mathrm{t} \leq 0,05 \mathrm{H} 1$ diterima $\mathrm{H} 0$ ditolak (artinya secara parsial terdapat pengaruh yang signifikan antara luas lahan, bibit, tenaga kerja, pupuk organik, pupuk NPK, dan pestisida terhadap produksi bawang merah di Kecamatan Wanasari). 


\section{HASIL DAN PEMBAHASAN}

\section{Karakteristik Responden}

Gambaran umum karakteristik responden petani bawang merah di Kecamatan Wanasari 2017 dikelompokkan berdasarkan usia, jumlah anggota keluarga, tingkat pendidikan, dan pengalaman bertani. Tabel 1 menunjukkan bahwa petani responden yang berusia 41-50 tahun sebanyak 34 responden atau sebesar 37,4\%. Petani responden menunjukkan kisaran dalam usia produktif, artinya usahatani bawang merah dapat dikerjakan secara optimal dengan mencurahkan tenaga kerja fisik yang tersedia. Menurut Asih (2009) bahwa umur dalam hal ini dapat mempengaruhi petani dalam mengambil keputusan, umur muda memungkinkan petani mampu mengelola usahatani yang telah digeluti bertahun-tahun seoptimal mungkin dengan curahan tenaga fisik yang tersedia.

Sebagian besar anggota keluarga petani yang masih menjadi tanggungan kepala keluarga petani adalah istri, anak, serta orangtua berjumlah 4-6 orang sebanyak 68 orang atau sebesar $74,8 \%$. Semakin banyak jumlah anggota keluarga biasanya semakin tinggi peluang menjadi sumber tenaga kerja dalam keluarga. Namun menurut Asih (2009) bahwa jumlah anggota keluarga merupakan sumber tenaga kerja dalam berusahatani bawang merah, tetapi semakin banyak tenaga kerja maka semakin tinggi pula biaya yang harus dikeluarkan untuk konsumsi dan semakin kecil dana yang dapat dialokasikan untuk biaya usahatani.

Jumlah petani responden sebagian besar berasal dari latar belakang pendidikan yang rendah. Latar belakang pendidikan yang rendah tersebut dilihat dari lamanya waktu menempuh sekolah yang sangat singkat, dan sebagian besar responden bersekolah hanya sampai tamat SD yaitu sebanyak 48 responden atau sebesar 52,8\%. Tingkat pendidikan sangat mempengaruhi cara berpikir dan pengambilan keputusan seorang petani. Menurut Aldila et al. (2015) bahwa pendidikan akan mempengaruhi cara berpikir petani dan tingkat penyerapan teknologi serta
Tabel 1. Identitas Responden

\begin{tabular}{|c|c|c|c|}
\hline No. & $\begin{array}{c}\text { Karakteristik } \\
\text { Responden }\end{array}$ & Jumlah & Persentase \\
\hline & & orang & $\%$ \\
\hline \multirow[t]{7}{*}{1} & Umur (Thn) & & \\
\hline & $20-30$ & 4 & 4,4 \\
\hline & $31-40$ & 18 & 19,8 \\
\hline & $41-50$ & 34 & 37,4 \\
\hline & $51-60$ & 25 & 27,5 \\
\hline & $>60$ & 9 & 9,9 \\
\hline & Jumlah & 90 & 100,0 \\
\hline \multirow[t]{6}{*}{2} & Anggota & & \\
\hline & Keluarga (Org) & & \\
\hline & $1-3$ & 19 & 20,9 \\
\hline & $4-6$ & 68 & 74,8 \\
\hline & $>7$ & 3 & 3,3 \\
\hline & Jumlah & 90 & 100,0 \\
\hline \multirow[t]{8}{*}{3} & Tingkat & & \\
\hline & Pendidikan & & \\
\hline & Tidak Sekolah & 3 & 3,3 \\
\hline & SD & 48 & 52,8 \\
\hline & SMP & 16 & 17,6 \\
\hline & SMA & 21 & 23,1 \\
\hline & S-1 & 2 & 4,4 \\
\hline & Jumlah & 90 & 100,0 \\
\hline \multirow[t]{8}{*}{4} & $\begin{array}{l}\text { Lama Bertani } \\
\text { (Thn) }\end{array}$ & & \\
\hline & $1-10$ & 11 & 12,1 \\
\hline & $11-20$ & 30 & 33,0 \\
\hline & $21-30$ & 28 & 30,8 \\
\hline & $31-40$ & 16 & 17,6 \\
\hline & $41-50$ & 3 & 3,3 \\
\hline & $>50$ & 2 & 2,1 \\
\hline & Jumlah & 90 & 100,0 \\
\hline
\end{tabular}

Sumber: Analisis Data Primer, 2017.

ilmu pengetahuan.

Jumlah petani responden yang memiliki pengalaman bertani 11-20 tahun sebanyak 30 responden atau sebesar $33,0 \%$, yang artinya usahatani bawang merah di Kabupaten Brebes salah satunya Kecamatan Wanasari merupakan usahatani yang sejak dulu dikembangkan dan dibudidayakan oleh masyarakat tersebut. Menurut Aldila et al. (2015) bahwa usahatani bawang merah di Kabupaten Brebes relatif lebih lama dikembangkan sehingga banyak petani yang 
sudah lama membudidayakan bawang merah baik secara mandiri maupun dari usaha turun temurun orang tua.

\section{Faktor-faktor yang Produksi Bawang Merah}

mempengaruhi

Faktor-faktor yang mempengaruhi Produksi Bawang Merah meliputi luas lahan (X1), bibit (X2), tenaga kerja (X3), pupuk organik (X4), pupuk NPK (X5), dan Pestisida (X6) terhadap produksi bawang merah (Y). Hasil analisis regresi linier berganda dapat dilihat di Tabel 2.

Berdasarkan hasil analisis uji $\mathrm{F}$ diperoleh nilai $F$ hitung sebesar 244,580 dan nilai

Tabel 2. Hasil Analisis Regresi Linier Berganda

\begin{tabular}{clrc}
\hline No & \multicolumn{1}{c}{ Variabel } & Koefisien & Sig. \\
\hline 1 & Konstanta & 773,482 & $0,000 * *$ \\
2 & Luas Lahan (X1) & 0,486 & $0,000 * *$ \\
3 & Bibit (X2) & $-0,972$ & $0,000 * *$ \\
4 & Tenaga Kerja (X3) & 5,816 & $0,000 * *$ \\
5 & Pupuk Organik & 1,475 & $0,012 *$ \\
& (X4) & & \\
6 & Pupuk NPK (X5) & $-2,745$ & $0,000 * *$ \\
7 & Pestisida (X6) & 0,346 & 0,029 \\
8 & F. hit & 244,580 & \\
9 & Adjusted R Square & 0,943 & \\
\hline
\end{tabular}

Sumber: Analisis Data Primer, 2017.

Keterangan: * signifikan

**sangat signifikan

signifikan sebesar $0,000 * *$ nilai signifikansi lebih kecil dari $0,05(\alpha=5 \%)$, dengan demikian penggunaan faktor produksi luas lahan, bibit, tenaga kerja, pupuk organik, pupuk NPK, dan pestisida berpengaruh secara serempak terhadap produksi bawang merah pada tingkat kepercayaan 95\%. Koefisien determinasi sebesar 0,943 atau $94,3 \%$ nilai produksi dijelaskan oleh variabel yang ada dalam produksi sebesar 94,3\%.

Berdasarkan hasil analisis uji $t$ dapat diketahui bahwa nilai signifikan pada faktor luas lahan, bibit, pupuk organik, pupuk NPK, dan pestisida memiliki nilai lebih kecil dari $0,05(\alpha=5 \%)$ dengan demikian secara parsial luas lahan, bibit, tenaga kerja, pupuk organik, pupuk NPK, dan pestisida masing-masing berpengaruh nyata terhadap produksi bawang merah.

Hasil analisis yang telah dilakukan dapat diketahui bahwa luas lahan berpengaruh nyata terhadap produksi bawang merah pada nilai signifikansinya sebesar $0,000^{* *}$ atau kurang dari 0,01 $(\mathrm{p}<0,01)$. Berdasarkan koefisien regresinya sebesar 0,486 berarti setiap penambahan 1 hektar luas lahan maka akan meningkatkan hasil produksi sebesar $0,486 \mathrm{~kg}$ per masa panen, dengan asumsi variabel lain tetap atau konstan. Lahan merupakan modal awal seorang petani untuk menjalankan usahataninya, semakin luas lahan yang digunakan untuk usahatani bawang merah maka produksi yang dihasilkan juga akan semakin meningkat. Dengan demikian luas lahan memiliki pengaruh yang positif dengan produksi bawang merah. Hal ini sesuai dengan pendapat Sumiyati (2006) yang menyatakan bahwa luas lahan merupakan faktor utama dalam usahatani karena terkait dengan keberlangsungan usahatani. Didukung oleh pendapat Andriyani (2014) yang menyatakan bahwa lahan sebagai media tumbuh tanaman merupakan salah satu faktor produksi yang penting dalam pengelolaan usahatani, semakin luas lahan yang ditanami bawang merah maka semakin tinggi pula produksi yang dihasilkan dan sebaliknya semakin sempit lahan yang ditanami maka semakin rendah pula produksi yang dihasilkan.

Variabel bibit berpengaruh nyata terhadap produksi bawang merah pada taraf signifikan $\alpha=5 \%$ dimana nilai signifikansinya sebesar 0,000 lebih kecil dari $0,005(\alpha=5 \%)$. Variabel bibit memiliki koefisien -0,972. Standar penggunaan bibit luasan 1 ha rata-rata 1,2 ton. Jumlah bibit yang digunakan oleh responden rata-rata $194,78 \mathrm{~kg} /$ ha dengan luasan 0,17 ha. Hal ini berarti penggunaan bibit sesuai standar, apabila penggunaan input bibit dinaikkan atau 
ditambah $1 \mathrm{~kg} / \mathrm{mt}$ maka akan menyebabkan penurunan produksi sebesar $0,972 \mathrm{~kg} / \mathrm{mt}$. Bibit merupakan input pertanian lain yang berpengaruh terhadap tingkat produksi usahatani. Penggunaan jumlah bibit yang sesuai kebutuhan dengan kualitas yang baik dapat menambah jumlah produksi. Hal ini sesuai dengan pendapat Wiguna et al. (2013) yang menyatakan bahwa dalam mendukung produktivitas bawang merah yang maksimal dibutuhkan umbi bibit yang bermutu tinggi. Umumnya petani di Kecamatan Wanasari menggunakan bibit milik sendiri dengan cara menyisihkan sebagian hasil panen bawang merahnya untuk dijadikan bibit di masa tanam berikutnya. Dalam menyisihkan umbi untuk dijadikan bibit, petani tetap melakukan seleksi yaitu pada saat mengamati kondisi pertumbuhan tanaman di lapangan untuk mengambil keputusan tentang penyisihan sebagian hasil panen untuk dijadikan bibit.

Hasil analisis uji parsial yang telah dilakukan dapat diketahui bahwa variabel tenaga kerja berpengaruh nyata terhadap produksi bawang merah dimana signifikannya sebesar 0,000 lebih kecil dari 0,05 $(\alpha=5 \%)$. Variabel tenaga kerja memiliki koefisien 5,816. Hal ini berarti apabila penggunaan input tenaga kerja dinaikkan atau ditambah 1 HOK (Hari Orang Kerja) maka akan diperoleh peningkatan produksi sebesar 5,816 $\mathrm{kg} / \mathrm{mt}$, dengan asumsi variabel lain tetap atau konstan. Tenaga kerja petani bawang merah di Kecamatan Wanasari rata-rata 296,625 HOK/ $\mathrm{mt}$ (Hari Orang Kerja) dengan rata-rata penggunaan luas lahan 0,17 ha. Tenaga kerja merupakan faktor penting dalam menunjang keberhasilan usahatani, tenaga kerja sangat dibutuhkan pada saat mulai melakukan pembibitan, pengolahan lahan, tanam, pemeliharaan, menyemprotan, pemupukan, panen dan pasca panen.Tenaga kerja yang digunakan di Kecamatan Wanasari rata-rata memiliki umur yang produktif dan lama bertani dengan waktu yang cukup lama 11-20 tahun. Hal ini sesuai dengan pendapat Novitasari (2017) yang menyatakan bahwa faktor produksi tenaga kerja merupakan faktor produksi penting lainnya dan perlu diperhitungkan dalam proses produksi. Selain jumlah ketersediaan tenaga kerja, kualitas dan macam tenaga kerja merupakan hal penting yang juga perlu diperhatikan. Kerja seseorang dipengaruhi oleh umur, pendidikan, keterampilan, pengalaman dan tingkat kesehatan.

Hasil analisis uji parsial yang telah dilakukan dapat diketahui bahwa variabel pupuk organik berpengaruh nyata terhadap produksi bawang merah dimana signifikannya sebesar 0,012 lebih kecil dari 0,05 $(\alpha=5 \%)$. Variabel pupuk organik memiliki koefisien 1,475. Hal ini berarti apabila penggunaan input pupuk organik dinaikkan atau ditambah $1 \mathrm{~kg} / \mathrm{mt}$ maka akan menyebabkan peningkatan produksi sebesar $1,475 \mathrm{Kg} / \mathrm{mt}$, dengan asumsi variabel lain tetap atau konstan. Penggunaan pupuk organik di Kecamatan Wanasari rata-rata $28,33 \mathrm{~kg} / \mathrm{mt}$. Pupuk organik merupakan salah satu faktor penentu meningkatnya produksi bawang merah. Hal ini sesuai pendapat Samad (2010) bahwa pupuk organik memiliki kemampuan untuk mempercepat proses pertumbuhan tanaman bawang merah secara merata pada permukaan tanah. Penggunaan pupuk organik yang cukup maka unsur-unsur hara makro dan mikro terpenuhi sehingga sel tanaman untuk pembentukan buah dan umbi bawang merah lebih sempurna.

Hasil analisis uji parsial yang telah dilakukan dapat diketahui bahwa variabel pupuk NPK, berpengaruh nyata terhadap produksi bawang merah dimana signifikansi sebesar 0,000 lebih kecil dari 0,05 $(\alpha=5 \%)$. Variabel pupuk NPK memiliki koefisien 2,745. Hal ini berarti apabila penggunaan input pupuk NPK ditambah $1 \mathrm{~kg} / \mathrm{mt}$ maka akan menyebabkan penurunan produksi sebesar $2,745 \mathrm{Kg} / \mathrm{mt}$, dengan asumsi variabel lain tetap atau konstan. Penggunaan pupuk NPK di Kecamatan Wanasari rata-rata sebesar $50,89 \mathrm{Kg} / \mathrm{mt}$. Pemberian pupuk anorganik seperti pupuk NPK, dengan dosis yang tidak tepat tidak dapat meningkatkan hasil dari kualitas maupun kuantitas produksi usahatani bawang merah. Hal ini sesuai pendapat Winarto dan Napitupulu (2010) yang 
menyatakan bahwa pemupukan merupakan salah satu faktor penentu dalam upaya meningkatkan hasil tanaman, pupuk yang digunakan secara berlebihan tidak dapat memberikan hasil yang maksimal. Pupuk NPK adalah suatu jenis pupuk majemuk yang mengandung lebih dari satu unsur hara yang digunakan untuk menambah kesuburan tanah. Keuntungan dari penggunaan pupuk NPK ialah mengandung unsur $\mathrm{N}, \mathrm{P}, \mathrm{K}$, dan unsur hara sekunder $\mathrm{CaO}$ dan $\mathrm{MgO}$, memberikan keseimbangan unsur nitrogen, fosfat, kalium, dan magnesium terhadap pertumbuhan tanaman (Maharaja et al., 2015).

Hasil analisis uji parsial yang telah dilakukan dapat diketahui bahwa variabel pestisida berpengaruh nyata terhadap produksi bawang merah dimana signifikannya sebesar 0,029 lebih kecil dari 0,05 $(\alpha=5 \%)$. Variabel pestisida memiliki koefisien 0,346. Hal ini berarti apabila penggunaan input pestisida ditambah 1 liter/mt maka akan menyebabkan peningkatan produksi sebesar 0,346 liter/mt, dengan asumsi variabel lain tetap atau konstan. Penggunaan pestisida di Kecamatan Wanasari sebesar 108,01 liter/mt. Pemberian pestisida digunakan sebagai pencegahan hama dan penyakit yang menyerang pada tanaman bawang merah, penggunaan pestisida dengan dosis yang tepat akan menghindari hama dan penyakit yang akan menyerang tanaman bawang merah dan membantu pertumbuhan tanaman bawang merah tetap terjaga sampai menjelang panen. Hal ini sesuai pendapat Satria (2015) yang menyatakan bahwa dalam bidang pertanian, pestisida merupakan bahan kimia yang digunakan untuk membunuh organisme pengganggu tanaman. Penggunaan pestisida dapat bermanfaat untuk meningkatkan produksi pertanian apabila digunakan dengan dosis yang tepat dan dikelola dengan baik akan menimbulkan dampak yang positif.

\section{SIMPULAN DAN SARAN}

1. Faktor produksi luas lahan, bibit, tenaga kerja, pupuk organik, pupuk NPK, dan pestisida secara serempak berpengaruh terhadap produksi bawang merah, koefisien determinasi sebesar 0,943 .

2. Secara parsial luas lahan, bibit, tenaga

kerja, pupuk organik, pupuk NPK, dan pestisida berpengaruh nyata terhadap produksi bawang merah.

Berdasarkan hasil penelitian saran yang dapat diberikan adalah bahwa petani bawang merah di Kecamatan Wanasari dapat menggunakan sistem diversifikasi dengan tanaman lain, menambah pupuk organik, pupuk NPK, dan pestisida untuk meningkatkan produksi bawang merah, sedangkan penggunaan bibit yang berkualitas dapat digunakan dengan jumlah yang sesuai dan tidak berlebihan dengan asumsi penggunaan bibit yang berlebihan tidak akan menambah jumlah produksi. Penggunaan sistem diversifikasi merupakan salah satu usaha untuk meningkatkan produksi tanpa menambah luasan lahan, dan penambahan pupuk organik, pupuk NPK, dan pestisida dapat dilakukan bertahap sesuai dengan kebutuhan masing-masing petani.

Penambahan pupuk organik sebelum masa tanam dimulai dapat memperbaiki struktur tanah dan meningkatkan ketersediaan hara di dalam tanah serta dapat meningkatkan kualitas hasil panen produksi usahatani bawang merah.

\section{DAFTAR PUSTAKA}

Aldila, H. F., A. Fariyanti dan N. Tinaprilla. 2015.Analisis pofitabilitas usahatani bawang merah berdasarkan musim di tiga kabupaten sentra produksi di Indonesia. Jurnal SEPA (Sosial Ekonomi Pertanian Agribisnis) 11(2): 249-260.

Andriyani, W. 2014.Analisis produksi dan pendapatan usahatani bawang merah lokal tinombo di Desa Lombok Kecamatan Tinombo Kabupaten Parigi moutong. Jurnal Agrotekbis 2(5): 533538.

Asih, D, N. 2009. Analisis karakteristik dan tingkat pendapatan usahatani bawang merah di sulawesi tengah. Jurnal Agroland 16(1): 53-59.

Badan Penelitian dan Pengembangan 
Pertanian. 2005. Prospek dan Arah Pengembangan Agribisnis. Departemen Pertanian Indonesia. Jakarta.

Badrudin, U. dan S. Jazilah. 2010. Analisis Residu Pestisida pada Tanaman Bawang Merah (Allium ascalonicum L.) di Kabupaten Brebes. Proceeding The First International Conference Technology on Biosciences and Social. 190-331.

Ghozali, I. 2007. Aplikasi Analisis Multivariate dengan Program SPSS.Universitas Diponogoro Semarang. Semarang.

Istina, I, N. 2016. Peningkatan produksi bawang merah melalui teknik pemupukan npk. Balai pengkajian teknologi pertanian riau. Jurnal Agroekoteknologi. 3(1): 36-37.

Kementerian Pertanian. 2014. Laporan Kinerja Perdagangan Komoditas pertanian.KEMENTAN Press. Jakarta.

Maharaja, P, D., T. Simanungkalit dan J. Ginting. 2015. Respons pertumbuhan dan produksi bawang merah (Allium ascalonicum $L$ ) terhadap dosis pupuk npkmg dan jenis mulsa. Program Studi Agroekoteknologi Fakultas Pertanian. Universitas Sumatera Utara. Medan. Jurnal Agroekoteknologi. 4(1): 19001910.

Novitasari. 2017. Analisis Pendapatan dan Faktor-Faktor yang Memengaruhi Produksi Bawang Merah (Allium Ascalonicum) di Dataran Tinggi Kecamatan Pangalengan Kabupaten Bandung.Program Studi Agribisnis Fakultas Ekonomi dan Manajemen Institut Pertanian Bogor. Bogor. (Skripsi S1 Pertanian).

Pramesti, G. 2014. Kupas Tuntas Data Penelitian dengan SPSS 22.PT Elex Media Komputindo. Jakarta.

Rahma, A. dan R. Sipayung. 2013. Pertumbuhan dan produksi bawang merah dengan pemberian pupuk kandang ayam dan em. Jurnal Agroekoteknologi. 1(4): 952-963.

Rahmawati, N. dan E. Istiyanti. 2011.
Elastisitas Permintaan Input dan Penawaran Output Bawang Merah ditinjau dari Fungsi Produksi. Jurusan Sosial Ekonomi Pertanian Fakultas Pertanian Universitas Muhammadiyah Yogyakarta.Yogyakarta. (Skripsi S-1 Pertanian).

Samad, S. 2010. Pengaruh Pupuk Organik terhadap Pertumbuhan dan Produksi Tanaman Bawang Merah di Lahan Kering Dataran Rendah.Fakultas Pertanian Universitas Khairun Ternate. Maluku Utara. (Skripsi S-1 Pertanian).

Satria, B, M. 2015. Penggunaan Aspergillus Niger yang Diradiasi Gamma Sebagai Bioremedian Residu Triazofos dan Logam Berat Pada Bawang Merah (Allium Cepa. L). Sekolah Pascasarjana Institut Pertanian Bogor. Bogor. (Tesis S-2 Pertanian).

Sumiyati. 2006. Analisis Pendapatan dan Efisiensi penggunaan Faktor-Faktor Produksi Usahatani Bawang Daun.Jurusan Sosial Ekonomi Pertanian Fakultas Pertanian Institut Pertanian Bogor. (Skripsi S-1 Pertanian).

Wiguna, G., C, I Azmi, dan M. Hidayat. 2013. Perbaikan teknologi produksi benih bawang merah melalui pengaturan pemupukan, densitas, dan varietas. Balai Penelitian Tanaman Sayuran di Lembang Bandung. Bandung. Jurnal Hortikultura 23(2): 137-142.

Winarto, L. dan D. Napitupulu. 2010. Pengaruh pemberian pupuk $\mathrm{N}$ dan $\mathrm{K}$ terhadap pertumbuhan dan produksi bawang merah. Balai Pengkajian Teknologi Pertanian Sumatera Utara. Jurnal Hortikultura 20(1): 27-35. 